\title{
MATHEMATICAL CONCEPTS FROM COMMUNITY ELDERS EXPLORING THE CONNECTION BETWEEN ETHNOMATHEMATICAL CONTEXTS AND CLASSROOM PRACTICES
}

\author{
CONCEITOS MATEMÁTICOS DE ANCIÃOS DA COMUNIDADE \\ EXPLORANDO A CONEXÃO ENTRE \\ CONTEXTOS ETNOMATÉMICOS E PRÁTICAS DE AULA
}

\author{
CONCEPTOS MATEMÁTICOS DE LOS ANCIANOS DE LA COMUNIDAD \\ EXPLORANDO LA CONEXIÓN ENTRE \\ CONTEXTOS ETNOMATEMÁTICOS Y PRÁCTICAS EN EL AULA
}

Mosimege Mogege

\begin{abstract}
Members of the community possess a wealth of knowledge in indigenous activities and artifacts. The analysis of the various indigenous activities and artifacts show a variety of mathematical concepts and processes. Even though some of the community members have not attended formal schooling or have not studied to a significantly high level, they are able to use the related mathematical concepts with ease as they engage in the activities. This Report identifies some of the mathematical concepts that are embedded in the indigenous activities and shows how most of the community members use such mathematical concepts with ease. The report concludes by indicating how this knowledge can be used to advance mathematical understanding in the classroom.
\end{abstract}

KEYWORDS: Ethnomathematical Studies. Indigenous Games. Mathematical Analysis. Cultural Villages. Mathematics Classrooms.

\section{RESUMO}

Os membros da comunidade possuem uma riqueza de conhecimentos em atividades indígenas e artefatos. A análise das várias atividades e dos artefatos indígenas mostra uma variedade de conceitos e processos matemáticos. Mesmo que alguns membros da comunidade não tenham frequentado a educação formal ou não tenham estudado a um nível significativamente elevado, eles são capazes de utilizar os conceitos matemáticos relacionados com facilidade na medida em que se envolvem nas atividades. Este texto identifica alguns conceitos matemáticos que estão embutidos nas atividades indígenas e mostra como a maioria dos membros da comunidade utiliza esses conhecimentos matemáticos com facilidade. O texto conclui indicando como esse conhecimento pode ser utilizado para avançar a compreensão matemática em sala de aula.

PALAVRAS-CHAVE: Estudos Etnomatemáticos. Jogos Indígenas. Análise Matemática. Vilas Culturais. Aulas de Matemática.

\footnotetext{
${ }^{1}$ Doutor em Educação Matemática - Universidade do Cabo Ocidental - Cidade do Cabo, África do Sul. Especialista em pesquisa e chefe do programa Educação e Desenvolvimento de Habilidades (ESD). Especialista em pesquisa do Conselho de Pesquisa em Ciências Humanas (HSRC) - UNISA Universidade do Cabo Ocidental Universiteit van Wes-Kaapland Joanesburgo e Região, África do Sul. E-mail: mosimege@gmail.com Received on: 25/02/2017 - Accepted on: 08/06/2017
}
(C) ETD- Educação Temática Digital
Campinas, SP
v.19
n.3
p. $667-686$
jul./set. 2017 


\section{RESUMEN}

Los miembros de la comunidad poseen una riqueza de conocimientos en actividades y artefactos indígenas. El análisis de las diversas actividades y artefactos indígenas muestra una variedad de conceptos y procesos matemáticos. A pesar de que algunos de los miembros de la comunidad no han asistido a la educación formal o no han estudiado a un nivel significativamente alto, ellos son capaces de utilizar los conceptos matemáticos relacionados con facilidad a medida que participan en las actividades. Este texto identifica algunos de los conceptos matemáticos que están incrustados en las actividades indígenas y muestra cómo la mayoría de los miembros de la comunidad usan estos conocimientos matemáticos con facilidad. Este texto concluye indicando cómo se puede utilizar este conocimiento para avanzar en la comprensión matemática en el aula.

PALABRAS CLAVE: Estudios Etnomatemáticos. Juegos Indígenas. Análisis Matemáticas. Pueblos Culturales. Aulas de Matemáticas.

\section{INTRODUCTION}

Most participants in ethnomathematical studies who are approached for the depth and wealth of their knowledge are the elderly members in various communities (at times referred to as elders, knowledge holders, knowledge owners, knowledge practitioners, etc.). These are indigenous and local members of the different communities who have used indigenous knowledge for survival and for dealing with the environment in which they live. This knowledge has been learnt from their parents and grandparents and other community members, meaning that it has been passed from generation to generation mostly by word of mouth, most of it is not recorded although it can be argued that there were other forms in which this knowledge was kept such that it was not lost or most of it could still be preserved, retrieved and used.

Community members have learnt how to count and to measure and to deal with many activities that require and use mathematical knowledge regularly. These activities, and others, are part of the environmental activities that are significant, both separately and in interaction, for the development of mathematical ideas in any culture (BISHOP, 1988). These community members (especially the elderly) have learnt these through various processes that they have engaged in regularly without doing it formally in a classroom situation as most of them have not been able to attend formal school. Even those who had an opportunity to attend formal school (mostly at primary school level, and a few others beyond this level, that is, secondary level and even fewer at tertiary level) still got an opportunity to learn this outside the school confines.

This form of knowledge has presented a challenge of inclusion within the school curriculum and various academic disciplines at universities as well as the mainstreaming and recognition of the knowledge. Actually the Indigenous knowledge Systems Policy (2004) in South Africa which was adopted by Cabinet in November 2004 alludes to the importance of
(C) ETD-Educação Temática Digital
Campinas, SP
v.19
n.3
p. $667-686$
jul./set. 2017 
accreditation of knowledge holders who have never been to school and so do not have formal qualifications yet have wealth of knowledge that is continuously and consistently used by researchers and pharmaceuticals for development of drugs and medicines.

In a study on Indigenous Games, Mosimege (2000) interviewed an elderly member of the community who is regarded as the champion of the Moruba game in the Mankweng Township outside the University of Limpopo in Polokwane, Limpopo Province, South Africa. At the time of the interview and the recording of the Moruba game the man was in his 70s. This elderly member of the community had never attended formal schooling, yet had been able to play and outclass some of the members of staff at the university, including professors. This Moruba champion and other regular players who are highly knowledgeable in the game had been identified through many days and months of my own personal observation and video recording of Moruba games being played and meeting regularly with him and other players at such games as he (Moruba champion) continued to display his ability and expertise as he played with other players. In this instance, the participants and the champion in the game had been identified after months and years of observation and interaction with players of the game.

Some studies reveal that even the younger members of the society may be found to be knowledgeable in various ethnomathematical activities. When the Malepa (String Figure Game) are trialed in the classrooms, most learners exhibited in-depth knowledge of the game, including dispelling the myth regarding which games were for boys and which were for girls. In games traditionally known to be boys' games, girls showed to be equally knowledgeable, in some cases more knowledgeable than boys in some of the classroom demonstrations. It is therefore incorrect to assume that indigenous knowledge is only known by the elderly, and that certain indigenous activities are an exclusive domain for boys or girls as illustrated in some of the excerpts below.

Games have traditionally been classified as either boys' or girls' games. For instance, the game of Diketo is generally known to be played by girls whereas Morabaraba, although not exclusively, is known as a boys' game. In writing about a similar game to Diketo in Mozambique (game called Mathakuzana), Mapapa (1995) indicates that there are many women traditions practised in the form of games, which implies that this is known as a woman's game.

The excerpt reported below is part of the interview on indigenous games that was conducted with a Councillor (member of the Advisory Council of the Chief) of the Barolong
(C) ETD-Educação Temática Digital
Campinas, SP
v.19
n.3
p. $667-686$
jul./set. 2017 
Tribe in Mafikeng, which is the capital of the North West Province. At the time of the interview he was 78 years old. Although the councillor had not attended school, he played an important role as a Councillor in the Barolong tribe which advises the Chief of the tribe on matters relating to the governance of the tribe. He also indicated to me that one of his roles as a Councillor is in the allocation of tribal land - including measuring the area that is to be given to an applicant - to the different community members who fall under the tribal jurisdiction of Chief Montshioa of the Barolong tribe. MDM are the initials of the researcher, GSM the initials for the Councillor.

In the interview below (GSM) explains, albeit briefly, that both boys and girls play the diketo and morabaraba games. The language used in both excerpts is Setswana, which is predominantly spoken in the North West Province.

MDM(7): So go raya gore bo Diketo, bo Morabaraba ba, gase, re ka tsaya gore gase motshameko wa basetsanyana hela kgotsa basimanyana hela. [So it means that games like Diketo, and Morabaraba, they are not, we can take it that they are not strictly for boys or girls only].

GSM(7): No. Ba a kopana. [No. They mix].

MDM(8): Ba a kopana. [They mix].

GSM(8): Go laola hela gore wena o batla go kgatlhega go ithuta go itse le wena. [It depends on you how much are you interested to learn as well].

The view that games like these, especially the Diketo game is not strictly a boys' or a girls' game is echoed by another interviewee (ISM) as shown in the excerpt below:

MDM(74): E nngwe e ke e gopolang ke Diketo. Diketo a e ne ele...Jaanong rona ha re gola re itse diketo ele motshameko wa basetsanyana. A basimanyana le bone ba ne ba o tshameka ka nako ya nyena? [The other game that I remember is Diketo. Diketo was...Well, when we grew up, we knew this game to be a girls' game. Did the boys play this game during your time?].

ISM(74): Ka nako ya rona diketo basimanyana ba [During our time in the Diketo game boys were].

MDM(75): Akere mos Diketo ke tse o epang lehuti ha hatshe? [By the way the Diketo game is a game in which you dig a hole on the ground?].

ISM(75): O epa lehuti. [You dig a hole].

MDM(76): Jaanong o bo o latlhela maje mo o a bala. Jaanong o bo o nna o tsholetsa o ya ko godimo o ntse o a ntsha. O ntse [And then you throw a stone up and count the other stones. And then you continue to throw this stone up and removing the rest. You continue to].

(C) ETD-Educação Temática Digital Campinas, SP $\quad$ v.19 n.3 $\quad$ p. 667-686 jul./set. 2017 
ISM(76): Le basimanyan [And the boys].

MDM(77): Le basimanyana ba ne ba o tshameka motshameko. [And the boys also played the game].

ISM(77): Ba ne ba o tshameka motshameko o. [The boys played this game]

MDM(78): Ooh. O ne o sa ile gore ke motshameko wa basenyana hela. Le ha gore tota re o bona okare o t/waetswe ke basenyana hela, ga go a siama gore re re ke motshameko was basenyana hela. [Ooh. The game was not strictly a girls game. Even though it looks like it is very popular with girls, it is incorrect to say that it is a girls' game].

ISM(78): E. Ke wa bana, ke wa bana ha ba ntse ba fatlhoga jalo. [It is for all the children when they grow up].

This excerpt of the interview with ISM focussed strictly on the Diketo game, although the rest of the interview was done in the context of the variety of indigenous games. Both GSM's and ISM's views that it is a myth to regard most of the games as strictly boys' or girls' games are also supported by the Johannesburg Society for the Blind. In the rules for the Diketo game which the Society has written reference is made to the player as a she but explains at the end of the rules that 'although the player is referred to as a she, this is only for convenience as both men and women enjoy playing the game'. The playing of the game by both males and females helps to dispel another misunderstanding in terms of household chores in which boys were to look after the cattle and the girls helped at home.

This is important for the introduction and use of such games in mathematics classrooms as it means that both boys and girls will benefit from the games, and not one game favouring particularly a certain group according to its gender. However, it is important that before any indigenous game is used in the classroom context, issues relating to gender and age are investigated to ensure that all learners benefit, so that misunderstandings are not perpetuated.

In a study on Learning about Geometry through the Construction of Wire Cars, Mogari (2002) indicates that the activity of constructing wire toy cars is normally carried out by boys who are in their early teens. In the classroom introduction this activity was given to male and female learners in Grade 9 classrooms and presented a variety of problems in which boys seemed to be favoured by the nature of the cultural artefact.

\section{MATHEMATICS IN TRADITIONAL AFRICAN GAMES}

$\begin{array}{llllll}\text { (C) ETD- Educação Temática Digital } & \text { Campinas, SP } & \text { v.19 } & \text { n.3 } & \text { p.667-686 } & \text { jul./set. } 2017\end{array}$


Doumbia (1989) reports on the work of the Institute of Research in Mathematics in Abidjan (IRMA), Ivory Coast, on mathematics in traditional African games. The work of the Institute, just like some of the ethnomathematical research, develops out of a response to 'a dominance of educational games coming from outside'. In the context of the IRMA work on the traditional African games, outside is taken to mean coming out of Africa and therefore their work, according to Doumbia, is intended to recognize the value of traditional African games so that Africa is represented within the development of mankind. This relates to the emancipatory aspect of ethnomathematics, in this case, specifically, using traditional games to challenge the dominance of what may be classified as Eurocentric games.

In an example of analysis of African traditional games the IRMA has calculated probabilities of the Cowrie game. In this game two players throw four cowrie shells (sea shells which land either up (+) or down (-), but not with equal likelihood). The points scored are as follows:

$$
\begin{aligned}
& +++5 \text { points } \\
& +--\quad 10 \text { points } \\
& ++--2 \text { points } \\
& +--\quad 0 \text { points } \\
& +++-0 \text { points }
\end{aligned}
$$

The random variable $X$ which for one throw of the cowries corresponds to the number of points obtained is defined as follows:

$$
\begin{aligned}
& \text { \{ } 0 \text { with probability of } 312 / 625 \\
& X=\{2 \text { with probability of } 216 / 625 \\
& \text { \{ } 5 \text { with probability of } 16 / 625 \\
& \text { \{ } 10 \text { with probability of } 81 / 625
\end{aligned}
$$

This shows that without any knowledge of the calculation of probability, the players have managed, by their attempts, to adopt a clever counting system, in order to balance their chances. The probability of scoring some points is $313 / 625$, which is $50.08 \%$ as against $312 / 625$, which is $49.92 \%$.

Mathematical Analysis of Indigenous Activities and Artifacts

(C) ETD-Educação Temática Digital $\quad$ Campinas, SP $\quad$ v.19 $\quad$ n.3 $\quad$ p.667-686 $\quad$ jul./set. 2017 
There are many other examples of mathematical analysis of indigenous activities that have not been included in this discussion but have been reported in other conference proceedings, books and journals. For instance, see Gerdes (1999), Cherinda (2002), Ismael (2002), Ismael and Mosimege (2004), Laridon, Mosimege and Mogari (2004), Mosimege and Ismael (2004), Nkopodi and Mosimege (2009).

These articles and published works do not only focus on the mathematisation processes of indigenous activities, but they also go beyond mathematical modelling aim (real life and contextual problems) to include the history of the activities and in a way address the other specific aims of inclusion of history of mathematics as well as access of mathematical content to all learners from different socio-cultural backgrounds.

\section{MATHEMATICAL CONCEPTS IN INDIGENOUS GAMES AS EXPLAINED BY THE COMMUNITY ELDERS}

A Morabaraba board (figure 1) is made up of straight lines forming three different squares whose angles and midpoints are joined by straight lines.

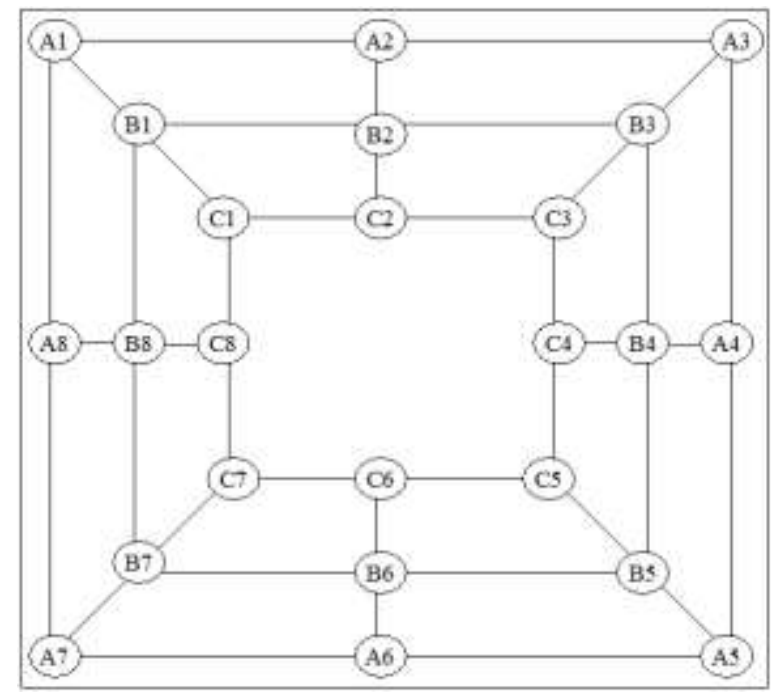

FIGURE 1 - Morabaraba board

Source: Mosimege (2000)

In drawing the Morabaraba board, a fair amount of measurement is required to ensure that the size and proportionality of the squares is maintained. It is also necessary to ensure that the size of angles $\left(90^{\circ}\right)$ and the lines joining the angles and the midpoints are properly done. Historically, the present measuring instruments were not available; instead
(C) ETD-Educação Temática Digital
Campinas, SP
v.19
n.3
p. $667-686$
jul./set. 2017 
measurement was done using bokwetse. This is the bark of a shrub whose branches are very straight and can therefore serve a very good purpose in drawing straight lines.

(i) Measurement and Straightness of Lines

MDM(119): Jaanong maar nyena lo ne lo sa lebelele ka dipalo mme hela lo ne lo itse gore lo a sega go straight. Lo ne lo thusiwa ke eng? [Now you did not look at mathematics yet you knew how to draw straight lines. What helped you?].

GSM(119): E. Akere jaanong re a thamalatsa re lebelela gore. [Yes. We make them straight and check that].

MDM(120): Lo thamalatsa ka eng Rre Matsheka. [What do you use to make straight line Mr Matsheka?].

GSM(120): Ha re sega jaana. [When we draw like this].

MDM(121): Ha lo sega jaana. [When you draw like that].

GSM(121): E. Akere jaanong re na le, re nale selo se bareng bokwetse. [Yes. Well, we have, we have what we call bokwetse].

MDM(122): Bokwetse? [Bokwetse?].

GSM(122): A kere jaanong bokwetse ke selo se re se kakabololang mo thupeng ya moret/wa. [Bokwetse is something that is removed from one of the shrubs called moret/wa].

MDM(123): Mo thupeng ya moret/wa? [From the moret/wa shrub].

GSM(123): Lekwati le la teng. [The buck thereof].

MDM(124): Lekwati le la teng le. Alright. [The buck thereof. Alright].

GSM(124): O ira tape ka lone ga kere? [You use it to make a tape, isn't it?].

MDM(125): Tape? Alright.

GSM(125): Jaanong o tlile go theipa ha o thamalatsa jaanong. [Now you measure when you make straight lines].

MDM(126): Ha o thamalatsa, o segela mo go yone. [When you make straight, you use it to draw the lines].

GSM(126): Mo go yone. [On it].

MDM(127): So go raya gore bokwetse, o dirisa jone gantsi go bontsha gore go thamalale. [So it means that you use bokwetse many times to draw straight lines]. $\operatorname{GSM}(127):$ E. [Yes].

MDM(128): Mme di thamalala? [And then they become straight?].

GSM(128): Go thamalala. [They become straight].

(C) ETD-Educação Temática Digital $\quad$ Campinas, SP $\quad$ v.19 $\quad$ n.3 $\quad$ p.667-686 $\quad$ jul./set. 2017 
In Mr. Mosimege's experience (ISM 90), they did not use anything to make the lines straight.

MDM(90): Jaanong lo ne lo sega. A kere gore, gore gonne straight, lo ne lo sega ka eng? Lo ne lo lepantsha ka eng? A kgotsa lo ne lo sega hela ka thogo? [Now you drew...Isn't it that, so that it can be straight, what did you use to draw? What did you use to make things straight? Did you just use your heads i.e. without using anything to measure?].

ISM(90): Nnyaya. Go ne go sena selo se se lekantshang. Hela o ne o sega o rata go bona yo o setswerere. Yo o setswerere tsela tsa gagwe di tla thamalala. \{As he explains the straight lines he illustrates the straightness with his right hand\} [No. There was nothing to measure. However you drew with the idea to see the one who was excellent at drawing and making the lines. The one who is excellent the lines will be straight] \{As he explains the straight lines he illustrate the straightness with his right hand\}.

However, despite the fact that they did not use anything to make the lines straight, they still had to ensure that the lines were straight. In his explanation (ISM 91-93) he uses the movement of a snake to illustrate the straightness of the lines, stressing that anybody who was called upon to draw a Morabaraba board was expected to ensure that the lines drawn did not resemble the lines made by the movement of a snake. After this explanation he once more emphasizes the importance of the straightness of the lines (ISM 94-96).

\section{(ii) Estimation and Comparison of Lengths}

Mr. Matsheka uses his hand to show that the length of the diagonal is longer than the length of the side of the smaller square (GSM129). He mentions that moving from the diagonal to the length of the square the length gets reduced (GSM131). Although no specific measurement unit is used, this estimation by Mr Matsheka can actually be verified. He is showing here that various lengths of lines can be compared and used in a variety of mathematical topics. This is an illustration of the highest level of the sense of estimation and comparison of the different lines.

$M D M(129):$ Jaanong, gore tse di mo gare tse \{pointing the lines of the small inner square\}, le line e Rre Matsheka \{pointing at the lines of the middle square\}, le e e ka mo ntle e \{pointing at the lines of the big outer square\} di lekane o ne o di lekantsha ka eng? [Now these lines inside \{pointing the lines of the small inner square\}, and this line Mr. Matsheka \{pointing at the lines of the middle square\}, and the one outside \{pointing at the lines of the big outer square\}, in order that they be equal, what did you use to make them equal?].

GSM(129): No. Akere jaanong bokwetse jo ha o dira jaana [No. This "bokwetse" when you do this] \{uses the thumb and the index finger to indicate the length of the diagonal distance between the outer and the inner square\}, bo tshwana le tape. O lebelela gore go tshwanetse
(C) ETD-Educação Temática Digital
Campinas, SP
v.19
n.3
p. $667-686$
jul./set. 2017 
go lekane jang [it is like a tape. You have to look at how these things must be equal] \{uses both hands to show how the tape between two points is held for measuring\}; Jaanong ha boya ko bokhutshwanyaneng o a bo riana [Now when it goes to the shorter sides you do this] \{he is referring to the one length of the small inner square as he uses both hands again for showing measurement\}, ka ha bokhutshwanyaneng. [on the shorter sides] \{lt looks like the sense of estimation of Mr Matsheka is excellent as even though he has not really measured he realises that the length of the line of the small square is shorter than the length of the diagonal line joining the three squares. This may not only be an estimation but knowledge of the different lengths from his knowledge of the Morabaraba game\}.

$\operatorname{MDM}(130)$ : O a bo riana. [You do this].

GSM(130): Akere tape ha e theipa jaana [when you use the tape like this] \{showing the junctions $C 3$ and $A 3$ which are the endpoints of the diagonal side C3B3A3\} ha e ya ko bokhutshwanyaneng [when it goes to the shorter side] \{showing the length of the side of the small square on $\mathrm{C}_{3} \mathrm{C} 4 \mathrm{C5}$ \} number ele e a ngotlega. [the number gets reduced].

MDM(131): Ooh. E. Alright. Alright. Number ele e a fokotsega. [Ooh. Yes. Alright. Alright. The number gets reduced].

GSM(131): E tla go lekana ha. [It becomes equal here] \{shows the length of one of the sides of the small square the one on $\mathrm{C} 3 \mathrm{C} 4 \mathrm{C5}\}$.

Malepa: An Indigenous Game

Malepa (this is the Setswana name for String Figure Game) is a game that is popular with children in many parts of South Africa. The International String Figure Association has been gathering and distributing string figure knowledge from different countries since 1978. The different bulletins of the Association have a record of the different string figure activities from different countries, confirming the knowledge of these figures. Although the knowledge of string figure games is well spread, the emphasis seems to differ from country to country, or more specifically, from different parts of the world. Whereas in a particular community knowledge and emphasis may be on making gates, in another the concentration is on different figures which may be made by using strings.

Keith (1994) refers to the knowledge of string figures that his parents had, which they had forgotten but were triggered by the figures he made for them. His father could even remember what Keith knows as Jacob's ladder, which his father knew as Job's coffin. This is similar to the experiences that I encountered in some of the workshop which were conducted on string figures as part of an ethnomathematical project in South Africa (MOSIMEGE, 1997) and other ethnomathematical materials. The two instances illustrate not only the knowledge of string figures in different cultures, but also that string figures are a part of different cultures, although the focus or emphasis differs from one culture to
(C) ETD-Educação Temática Digital
Campinas, SP
v.19 n.3
p. $667-686$
jul./set. 2017 
another. For instance, Keith refers to Jacob's ladder which he is familiar with, and I refer to diheke (also known as diamonds) which I learnt as a small boy. Some of the children who took part in the study in which the demonstrations below were done did not know any 'diamonds', but were able to make monatlana (chicken legs or even affectionately called run-away by some learners) with ease.

This gives an indication of the specificity and different emphasis of the games, where the game, although it may be known from one place to another, is either played differently, that is, rules differ and possibly even versions of the same may be different, or the same game may have a different meaning and names attached to it, or even played under different socio-cultural circumstances.

\section{Mathematical Concepts in the Game of Malepa}

The mathematical concepts that are mentioned here were arrived at through an analysis of the different String Figures Gates. For analysis of more indigenous games and other games, see Nkopodi and Mosimege (2009) and Mosimege (2012). The analysis would involve a process in which the String Figure Gate is looked at from the mathematical point of view, looking out for geometric figures where such exists and using other forms of mathematical knowledge to make meaning of the activities in which patterns and generalisations thereof are possible. The analysis process also included making meaning of the statements that are made when the gates are performed, or looking at the implication of the steps taken in performing a particular gate.

\section{(i) Variety of Geometric Shapes and Figures}

In any string figure gate the following geometric figures may be identified: Angles, triangles, quadrilaterals (particularly rectangles and squares). The number of the geometric figures increases as the number of gates increases.

\section{(ii) Patterns, relations and functions}

An analysis of the String Figure Gates reveals a variety of relationships between the triangles and quadrilaterals, quadrilaterals and intersecting points, and the generalisations that result from these relationships. The generalisations between the different geometric figures are:

- triangles and quadrilaterals: $y=2 x+2$;

(C) ETD-Educação Temática Digital $\quad$ Campinas, SP $\quad$ v.19 $\quad$ n.3 $\quad$ p.667-686 jul./set. 2017


- quadrilaterals and intersecting points: $y=3 x+1$; and

- quadrilaterals and the number of spaces (spaces are given by the combination of triangles and quadrilaterals): $y=3 x+2$.

- (iii) Symmetry

Working with gates, a variety of symmetry types may be identified. Most of the gates show bilateral symmetry, particularly even numbered gates. Some of the gates exhibit reflection symmetry, for example Gate 2, while others have rotational symmetry, for example Gate 1. It is also possible to show radial symmetry; translational symmetry; and anti-symmetry. After making a specific gate, disentangling the string along a specific line of symmetry also ensures that the string does not get entangled. An interesting classroom activity could be to investigate which types of symmetry are associated with which String Gates.

Gibbs and Sihlabela (1996) have examined the geometric figures similar to the ones identified in (i) above and suggest that the loop of a string can be manipulated even further to create a variety of other geometric shapes. For instance, how the loop of the string can be manipulated to create an isosceles and equilateral triangle out of the existing one. In the same way, the string can be manipulated to create a kite or rhombus from the identified square or rectangle. This work would provide interesting explorations in secondary school mathematical explorations.

\section{MATHEMATICAL KNOWLEDGE OF COMMUNITY ELDERS AT CULTURAL VILLAGES}

Cultural villages have been part of the cultural landscape of South Africa over many years. Before 1994, they predominantly served the purpose of showing the divide between the different cultural groups and in a sense helped to perpetuate the stereotypes and differences between the different groups. After the birth of democracy in 1994 most of these villages were turned around and used to showcase the cultural diversity that populates South Africa. The number of cultural villages have increased and their status as tourists centres enhanced even more to attract tourists from other parts of the world to a country that had for many years been riddled with political differences and policies of segregation and apartheid.

Cultural villages still serve almost exclusively as tourist centres. Whilst this is an important development, especially for the economy of the country, questions have been raised about the purposes of the establishment of such villages and whether they really
(C) ETD-Educação Temática Digital
Campinas, SP
v.19
n.3
p. $667-686$
jul./set. 2017 
empower the predominantly black population of the country economically. Another argument that can be raised, which forms the major focus of the discussion of this paper, is that these villages can serve more educational purposes than just tourist centres. A mathematical analysis of the various artefacts and activities at the villages provides an opportunity to explore the mathematical concepts that are used regularly by inhabitants (workers) at such villages.

Each Cultural Village employs a number of people who are knowledgeable about cultural activities and can be able to enact them appropriately for the visitors. It is interesting to note that most of the villages (at least those I have visited) employ a number of the elderly in the community to be able to showcase various indigenous activities appropriately in their historical and socio-cultural background. The employees get involved in actively making the artefacts that are showcased and sold at the courier shops found at the villages. They also take an active part in the decoration of the villages, like the mural decorations at the Lesedi cultural village explained below. A brief analysis of most of the artefacts and activities at these villages exhibits a number of mathematical concepts that are associated with the different activities.

Gerdes (1999) indicates that the people of Africa south of the Sahara desert constitute a vibrant cultural mosaic, extremely rich in its diversity. Among these people are a variety of geometrical ideas as manifested in the work of wood and ivory carvers, potters, painters, weavers, mat and basket makers, and many other laborious and creative African men and women alike. Both men and women contribute creatively to these geometrical shapes. In fact Gerdes (1995) had earlier alluded to the work that women do in artefacts like decorated handbags, coiled baskets, string figures, decorated pottery, grass brooms, tattooing and body painting, bead ornaments, and mural decorations. Almost all the activities that Gerdes is referring to the ones found at different cultural villages.

In her book Africa Counts, Zaslavsky (1999) argues that Africans have made significant contributions to the development of counting and numbers and deserve a place in studies dealing with the subject. She then continues to write about the construction of the numerations system as experienced and practised in various countries in the African continent. A look at the Ndebele culture, especially at places like the Lesedi Cultural Village and the Botshabelo Historical Town expose the extent to which counting and numeration are used.

They also show how members of such communities who have not been privileged to attend school are able to do most of the cultural activities and artefacts that are embedded
(C) ETD-Educação Temática Digital
Campinas, SP
v.19
n.3
p. $667-686$
jul./set. 2017 
with a lot of mathematical concepts and processes. Beadwork and artefacts covered in beads are found in many cultural villages. Dabula (2000) has gone on to explore and identify mathematical concepts associated with beadwork like number patterns, geometrical shapes, tessellation, and various types of symmetry. The same is exhibited and can be investigated further in the Ndebele culture. Examples of these are discussed below in the excerpt of the Ndebele culture at the Lesedi Cultural Village.

\section{(iii) Estimation and Counting in Beadwork}

The following excerpt reports on the interview conducted with two Ndebele ladies at the Lesedi Cultural Village, Ms Y and Ms Z. The Lesedi Cultural Village is located in the Gauteng Province, South Africa. In the excerpt, the questions focus on how the ladies engage in beadwork activities and explore related mathematical concepts. It focuses specifically on how they use beads to engrave names of people on beadwork activities, but also refers to other beadwork activities. In the excerpt, $\mathrm{R}$ refers to the researcher and SS to Ms Z and LM to Ms Y. The ladies speak Isindebele, however, they also understand the Sesotho languages like Setswana and Sesotho, as a result the interview used both Isindebele and Sesotho as the latter is mostly understood by the researcher in comparison to Isindebele.

R: Le rutilwe ke mang ho sebetsa ka dibeads?[Who taught you to work with beads?].

SS: Si fundiswe uGogo. [We were taught by our grandmothers].

R: Ni fundiswe nini? Le rutilwe leng ho etsa dibeads? [When were you taught to work with beads?].

LM: Si fundiswe sise bancane. Si ne minyaka e 10. [We were taught when we were very young. We were 10 years old].

R: Nkgono yo a le rutileng, ene o ne a rutwa ke mang? [Who taught the grandmother who taught you to work with beads?].

LM: U fundiswe ngo mama wakhe. [She was taught by her mother].

$R$ : So ho raya hore hangata Gogo o ruta ngwana, ngwana yo ha a setse a hodile o ruta bana ba hae. Jwalo jwalo. [So it means that many a times grandmothers teach their children, and when these children have grown up they also teach their children, and it continues like that].

LM: Njalo njalo [It continues like that].

(C) ETD-Educação Temática Digital $\quad$ Campinas, SP $\quad$ v.19 $\quad$ n.3 $\quad$ p.667-686 jul./set. 2017 
R: Ho raya hore ha ho hlokahale hore le ye sekolong ho ithuta ho sebetsa ka dibeads? [It means you do not need to go to school to learn to work with beads.

SS: A siyanga a skoleni [We have never attended school].

R: Jwale le entse tsohle tse di leng mona [So have you done all beadwork items that re here?](Researcher asks pointing to all the items displayed around the ladies).

SS: Si enze konke, na nga se stolo. [We have done all the beadwork things here, including all the things in the store] (Sophie says this pointing to the back where the store is and the bead artefacts are sold).

R: Joale mona o etsang? [Now what are you doing here?] (Researcher asks what Lenah is doing, pointing to the artefact she is working on).

LM: Ngi enza igama le Manager wethu. [l am working on a name tag of our Manager].

R: Le etsa joang hore ho be straight? [How do you ensure that this part of the ornament you are making is straight?] (The researcher points to the straight part of the ornament in which LM is writing the name of the Manager at Lesedi Cultural Village. The Manager's name is Xolani).

LM: Indaba ise nhloko. $O$ ya yazi [The matter is here in the head] (Linah says this pointing to her head. Later on, she further explains that they take two beads at a time) O I stopa kabini ngale [You take two beads that side].

SS: Si khetha umqamu o linganayo. [You choose beads of the same size](This is an additional explanation from Sophie about how the straight lines are made and maintained. Sophie then continues to explain how various shapes are made, for instance indicating that when you want to start at the centre of any artefact, you start with a big bead to indicate the centre).

R: Le tseba joang hore mona ke bead e kgolo, mona ke e nnyane? [How do you know that here you put a large bead and here you put a small bead?].

LM: Si bona nga mehlo. [We can see with our eyes].

R: Manje, ni bona ka njane ukuthi ni fake esingakhi?[Now, how do you see that you Must put so many beads at a particular point?].

SS: Si ya zi bala. [We count them].

R: Kanti ni yazi kanjani ukubala? Ni the a niyanga esikolweni. [How do you count them? You told me you have not gone to school].
(C) ETD-Educação Temática Digital
Campinas, SP
v.19
n.3
p. $667-686$
jul./set. 2017 
SS: Si ya zibala.

R: Hai. Ni zi bala ka njani? Le mpoleletse hore ha le a ya sekolong. [No. How do you Count them? You told me that you have anot attended school].

SS: Si ya zi bala. Sithi Kunye, Bili, Thato, Kune, Hlano. Ku hla ngapha ngi ya jika Ngi bheke le [We count them. We say One, two, three, four, five. Then we make a turn to move in the other direction].

R: So, kutsho ukuthi ufuna u ku yenzani. If o batla ho etsa ntho e e riling, o a bala then o jike [So it depends on what you want to do. If you want a specific artefact, you Count and then make a turn].

SS \& LM: Yebo [yes] (The two ladies respond at the same time. The interview then continues to explore other artefacts and how they were made and what they mean in Ndebele culture).

In this excerpt of the interview with the two ladies, it emerges that they are using a variety of mathematical concepts that are part of the artefacts they are making. Firstly, they refer to straightness of lines in making some of the artefacts. One of the ladies attributes this to their sense of estimation and actually mentions that they just watch and get a sense that the line is a straight as they need it to be. She suggests that this is based on the experience they have gained in using this skill many times. However, Sophie further indicates that the straightness is also maintained through the size of beads that are used. In fact, she mentions that turns (angles) are made using different sizes of beads. Even though they have not attended school, they clearly demonstrate that they know how to count by counting from one to five. This counting is crucial in their activities as it determines the patterns and shapes they make.

In the context of indigenous knowledge which is passed from generation to generation, the ladies indicate that the knowledge of working with beads is generally passed from mother to daughter, and such skills can actually be taught to others, and in this case the young are nurtured into these activities, ensuring that the skills do not die but are kept alive for the benefit of the greater society, in this case, of the Ndebele people.

\section{ETHNOMATHEMATICAL CONTEXTS AND ACTIVITIES AND THE MATHEMATICS CLASSROOM}

Many ethnomathematical studies have shown that various mathematical concepts can be identified in different cultural activities. This approach has seen many
(C) ETD-Educação Temática Digital
Campinas, SP
v.19 n.3
p. 667-686
jul./set. 2017 
ethnomathematical studies being undertaken and a number of questions explored on the inclusion of ethnomathematical activities in mathematics classrooms. In the early days of the work on ethnomathematics, Borba (1990) connected ethnomathematics with modelling in informal education settings and asked the following critical questions: If ethnomathematics - with its concern with cultural background of students is brought into the curriculum debate - is combined with modelling, then different issues and questions may arise, such as:

(i) Can a common textbook be used with students from different backgrounds in different parts of a country?

(ii) How do we deal with multicultural classrooms?

Although the work by Mosimege (2012) did not necessarily attempt to answer the questions raised by Borba (1990), it explored critical issues related to methodological challenges when ethnomathematical research is carried. These issues deal with participant and knowledge holders in ethnomathematical research, the role of language and its implications for research and the implementation thereof in mathematics classrooms, and mathematical analysis of cultural artifacts. In a sense, ethnomathematical work (the exploration of mathematical concepts in their cultural settings and contexts) can be used to look at modelling of examples from cultural activities in a mathematics classroom. This approach, would go a long way towards making various mathematical concepts accessible to the learners as they would be connected to real life socio-cultural experiences.

In ethnomathematical studies, the researchers and mathematics educators are influenced by their own mathematical knowledge. This means that they need to have an appropriate level of mathematical knowledge in order to recognize mathematical concepts, principles and processes in any activity (including indigenous activity) when they see one. Whenever they observe an activity taking place, they consider and interpret it in relation to a variety of mathematical concepts that are possible, and the dominant ones are most likely those they have been largely involved in or have taken an active part in.

However, it is possible to do further and deeper analysis on a variety of mathematical aspects that a researcher has not necessarily been involved in, although this would be limited by the extent to which such mathematical concepts can be recognized or arrived at. It looks like a very important component in mathematical analysis is not to limit yourself to the amount and level of mathematical knowledge that you have been exposed to or have done before as this would reduce on the levels of mathematical analysis that is possible. It is also very useful to share your thoughts with other mathematicians and
(C) ETD-Educação Temática Digital
Campinas, SP
v.19
n.3
p. $667-686$
jul./set. 2017 
mathematics education researchers to help you consider other components that you may have not thought about.

The nature of the construct of indigenous games suggest that somebody needs to analyze the learners' activities to reveal related mathematical concepts and processes in their activities. Teachers are appropriately placed with their mathematical knowledge to translate the learners' knowledge into meaningful mathematical explorations. This is only possible when a platform is created in which learners' knowledge of activities outside the classroom is used to relate to mathematical knowledge in the classroom.

However, there are necessary imperatives to ensure that this is a success, as their use may convey negative connotations when these imperatives are not taken into account. The necessary aspects are:

(i) Indigenous games can also be analysed (mathematised) to reveal a variety of mathematical concepts that are useful in school mathematics.

(ii) When these games are analysed, the related historical, social, and cultural meanings and implications should be taken into account. Failure to consider the implications of these can lead to misconceptions and misunderstanding in the use of such games and as a result detract rather than enhance mathematical understanding. In other words, indigenous games should be considered in their entire context (historical, social and cultural), which is possible to find and use appropriately.

(iii) It is indeed true that games serve a variety of affective objectives when used in mathematics classrooms. However, games also serve a variety of cognitive objectives.

Therefore, there is a great potential to use indigenous games and other cultural artifacts in the mathematics classrooms.

\section{REFERENCES}

BISHOP, Alan J. Mathematical enculturation: a cultural perspective on mathematics education. Dodrecht, The Netherlands: Reidel, 1988.

BORBA, Marcelo C. Ethnomathematics and education. For the Learning of Mathematics, $v$. 10, n. 1, p. 39-43, 1990.
(C) ETD-Educação Temática Digital
Campinas, SP v.19 n.3
p. $667-686$
jul./set. 2017 
CHERINDA, Marcos. The use of a cultural activity in the teaching and learning of mathematics: exploring twill weaving with a weaving board in Mozambican classrooms. Unpublished Ph.D. Thesis. Johannesburg, South Africa: University of the Witwatersrand, 2002.

DOUMBIA, Salimata. Mathematics in traditional African games. In KEITEI, Christine (Ed.). Mathematics, education, and society. Science and Technology Education Document Series 35. Paris, France: UNESCO, 1989.

GERDES, Paulus. Ethnomathematics and education in Africa. Institute of International Education. Stockholm, Sweden: Stockholm Universitet, 1995.

GERDES, Paulus. Geometry from Africa: mathematical and educational explorations. Washington, DC: The Mathematical Association of America, 1999.

GIBBS, William; SIHLABELA, Mprophet. String figures. Mathematics in school, v. 25, n. 3, p. 24-27, 1999.

ISMAEL, Abdulcarimo. An ethnomathematical study of Tchadji: about a mancala type board game played in Mozambique and possibilities for its use in mathematics education. Unpublished Ph.D. Thesis. Johannesburg, South Africa: University of the Witwatersrand, 2002.

LARIDON, Paul, MOSIMEGE, Mogege; MOGARI, David. Ethnomathematics research in South Africa. In VITHAL, Renuka; ADLER, Jill; KEITEL, Christine (Eds.). Researching mathematics education in South Africa: perspectives, practices and possibilities. Chicago, IL: HSRC Press, 2004. pp. 133-162.

MAPAPA, Abelio. Children's games/toys for mathematics education: the case of Mozambique. In Kjaergard, Tore; Kvamme, Aasmund; Linden, Nora (Eds.). Proceedings of the Third International Conference of the Political Dimensions of Mathematics Education. Bergen, Norway: Caspar-Forlag, 1995.

MOGARI, David. An ethnomathematical approach to the teaching and learning of some geometrical concepts. Unpublished Doctoral Thesis. Johannesburg, South Africa: University of the Witwatersrand, 2002.

MOSIMEGE, Mogege D. Exploration of the games of Malepa and Morabaraba in South African secondary school mathematics education. Unpublished PhD Thesis. University of the Western Cape, 2000.

MOSIMEGE, Mogege D. The use of games in mathematics classrooms. In Sanders, M. (Ed.).

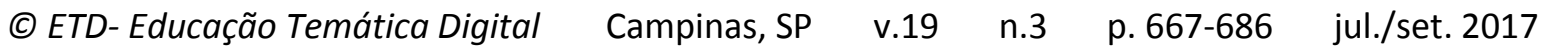


Proceedings of SAARMSE 5. Johannesburg, South Africa: University of the Witwatersrand. 1997.

MOSIMEGE, M.; ISMAEL, A. Ethnomathematical studies on Indigenous games: examples from Southern Africa. In F Favilli (Ed.). Ethnomathematics and Mathematics Education. Proceedings of the Discussion Group 15 of the $10^{\text {th }}$ International Congress on Mathematics Education. Pisa, Italy: University of Pisa, 2004.

MOSIMEGE Mogege D. Methodological challenges in doing ethnomathematical research. International Journal of African Renaissance Studies - Multi-, Inter- and Transdiciplinary, v. 7, n. 2, p. 59-78, 2012.

NKOPODI, Nkopodi; MOSIMEGE, Mogege D. Incorporating the Indigenous Game of Morabaraba in the Learning of Mathematics. South African Journal of Education, v. 29, p. 377-392, 2009.

ZASLAVSKY, Claudia. Africa counts: number and pattern in African cultures. Chicago, IL: Lawrence Hill Books, 1999.

'The grammatical and editorial revisions of this article were made by Daniel Clark Orey and Milton Rosa (UFOP). 